\title{
Effects of propolis on in vitro rumen microbial fermentation
}

\author{
Hakan OZTURK ${ }^{1}$, Mert PEKCAN ${ }^{2}$, Meltem SIRELI ${ }^{1}$, Ulvi Reha FIDANCI ${ }^{2}$ \\ ${ }^{1}$ Department of Physiology, Faculty of Veterinary Medicine, University of Ankara; ${ }^{2}$ Department of Biochemistry, Faculty of \\ Veterinary Medicine, University of Ankara, Turkey.
}

\begin{abstract}
Summary: The aim of this study was to investigate the effects of different concentrations of propolis ethanolic extract (PEE) on rumen microbial fermentation using the rumen simulation technique (Rusitec). Six fermenters with a nominal volume of $750 \mathrm{ml}$ were set up for the study that lasted 14 days. Each fermenter received daily $10 \mathrm{~g}$ of a basal diet consisting of $6 \mathrm{~g}$ pelleted alfalfa hay and $4 \mathrm{~g}$ pelleted concentrate. Treatments were control (received $0.5 \mathrm{ml} /$ day of $70 \%$ ethanol without having any propolis), $0.5 \mathrm{ml} / \mathrm{day}$ of $20 \%$ PEE, and $0.5 \mathrm{ml} /$ day of $60 \%$ PEE. Supplementation of PEE in both concentrations did not affect ruminal $\mathrm{pH}$, production of total short-chain fatty acid (SCFA) as well as of acetate, acetate to propionate ratio, total protozoa count, and dry matter digestibility. High concentration of PEE resulted in a significant decrease $(\mathrm{p}<0.05)$ in propionate production whereas both high and low concentrations of PEE significantly increased $(p<0.05)$ ruminal butyrate production. Total count of ruminal bacteria was decreased $(\mathrm{p}<0.05)$ after the addition of PEE in both concentrations. Furthermore, $\mathrm{NH}_{3}-\mathrm{N}$ concentration in rumen fluid was reduced $(\mathrm{p}<0.05)$ in a dose-dependent manner by 24 and $39 \%$ by the addition of low and high concentrations of PEE, respectively. In conclusion, the results of this study indicate that propolis may be a useful additive to decrease ruminal ammonia production and to improve the nitrogen utilization in ruminants.
\end{abstract}

Key words: In vitro, fermentation, propolis, rumen

\section{Propolisin rumen mikrobiyal fermantasyonu üzerine in vitro etkileri}

Özet: Bu araştırmada, Rusitec tekniği (Rumen Simulation Technique) kullanılarak, farklı yoğunluklardaki etanolik propolis ekstraktlarının rumen mikrobiyal fermantasyonu üzerine etkilerinin belirlenmesi amaçlandı. Gerçek hacimleri $750 \mathrm{ml}$ olan 6 fermenterin kullanıldığı araştırma 14 gün sürdü. Her bir fermenterde günlük olarak $6 \mathrm{~g}$ yonca otu peleti ve $4 \mathrm{~g}$ konsantre pelet yemden oluşan bir rasyon inkübe edildi. Araştırmadaki uygulama grupları kontrol (propolis içermeyen \% 70'lik etanol çözeltisinden $0,5 \mathrm{ml} /$ gün$)$, propolisin $\% 20^{\prime}$ lik etanolik ekstraktı ( $0,5 \mathrm{ml} /$ gün) ve propolisin \% 60'lık etanolik ekstraktı ( $0,5 \mathrm{ml} /$ gün) şeklindeydi. Rusitec fermenterlerine ilave edilen propolisin her iki yoğunluktaki ekstraktı da ruminal $\mathrm{pH}$, toplam kısa zincirli yağ asitleri ve asetat üretimleri, asetatın propiyonata oranı, toplam protozoon sayısı ve yem kuru maddesi sindirilebilirliklerinde istatistiksel bir değişime neden olmadi. Ancak \% 60'lık propolis ekstraktı propiyonat üretimini belirgin bir şekilde azaltırken ( $<0.05$ ), hem \% 60 hem de \% 20'lik propolis ekstraktı ruminal bütirat üretimini belirgin bir şekilde artırdı $(\mathrm{p}<0.05)$. Ayrıca her iki yoğunluktaki propolis ektraktı da ruminal bakterilerin toplam sayısında azalmaya $(\mathrm{p}<0.05)$ neden oldu. $\mathrm{NH}_{3}-\mathrm{N}$ konsantrasyonunda hem düşük hem de yüksek yoğunluktaki propolis ekstraktı ilavesinden sonra sırasıyla \% 24 ve \% 39'luk bir azalma $(p<0.05)$ belirlendi. Bu araştırmadan elde edilen sonuçlar propolisin ruminal amonyak üretimini azaltmada ve ruminal azot değerlendirilebilirliğini iyileştirmede kullanılabilecek bir katkı maddesi olabileceğine işaret etmektedir.

Anahtar sözcükler: In vitro, fermantasyon, propolis, rumen.

\section{Introduction}

A goal of ruminant microbiologists and nutritionists is to manipulate the ruminal microbial ecosystem to improve production efficiency of domestic ruminants. In these animals, the use of antibiotics as feed additives, such as ionophore antibiotics, has proved to be a useful tool to reduce the loss of energy as methane, and nitrogen as ammonia from the diet. However, due to the risk of transferring residues into meat and milk and resistant strains of bacteria, the use of antibiotics in animal nutrition has been prohibited in the European Union since January $2006(14,17)$. Thus, there is increasing interest in exploiting natural products as manipulators of ruminal fermentation.

Propolis is a resinous substance collected by honeybees from buds and leaves of trees and plants, mixing with pollen as well as enzymes secreted by bees (5). Substances, which are identified in propolis, generally are typical constituents of food and/or food additives, and are recognized as GRAS (Generally Recognized As Safe) substances (4). Numerous studies have proven its versatile pharmacological activities: antibacterial, antifungal, antiviral, anti-inflammatory, hepatoprotective, antioxidant, antitumoral, etc. (1). The 
antimicrobial activity was higher against Gram positive than against Gram negative bacteria (8). Gram positive bacteria produce more ammonia, hydrogen, and lactate than Gram negative species, and compounds that inhibit Gram positive ruminal bacteria have increased feed efficiency (23). Because propolis can inhibit the growth of Gram positive bacteria, it might be a useful additive for modifying microbial fermentation in the rumen. However, its potential for manipulating rumen microbial fermentation has not been widely assessed. The specific aim of the present study was to evaluate the effects of different concentrations of propolis ethanolic extract on rumen microbial fermentation in a long-term in vitro study.

\section{Material and Methods}

Incubation technique: The study was carried out using the rumen simulation technique RUSITEC (6). The complete unit consisted of six fermenters with an effective volume of $750 \mathrm{ml}$ each and the general incubation procedure was as described by Oeztuerk et al. (16). Rumen content was obtained from a pooled sample from two freshly slaughtered mature Merino sheep and transferred to the in vitro system within $30 \mathrm{~min}$. Animals had been fed $1.5 \mathrm{~kg} /$ day of a forage plus concentrate diet of $900 \mathrm{~g}$ pelleted alfalfa hay and $600 \mathrm{~g}$ commercial concentrate pellet. The same diet was also used for in vitro incubation trial. The complete unit of the Rusitec consisted of six fermenters with an effective volume of $750 \mathrm{ml}$ each. Each fermenter was loaded with 2 nylon bags $(70 \times 120 \mathrm{~mm}$ with a pore size of $150 \mu \mathrm{m})$. On day 1 , one bag was filled with $80 \mathrm{~g}$ of solid rumen contents to inoculate particle-associated microorganisms into the system and the other with the daily diet, a mixture of $4 \mathrm{~g}$ of pelleted concentrate and $6 \mathrm{~g}$ of pelleted alfalfa hay. The chemical composition of experimental diet is given in Table 1.

Table 1: Composition of the experimental diet (\%).

Table 1: Deneysel rasyonun bileşimi (\%).

\begin{tabular}{lcc}
\hline Ingredient & Pelleted alfalfa hay & Pelleted concentrate \\
\hline Dry matter & 88.5 & 87.5 \\
Crude protein & 18.1 & 17.6 \\
Crude lipids & 1.9 & 3.5 \\
Crude fibre & 18.4 & 5.4 \\
Total ash & 2.6 & 7.2 \\
\hline
\end{tabular}

The fermenters were filled with rumen fluid to inoculate fluid-associated microorganisms. The nylon bag with solid rumen contents was replaced after $24 \mathrm{~h}$ of incubation with a bag containing the daily diet. The feed bag was changed after $48 \mathrm{~h}$ so that 2 bags were always present. This gave a retention time of $48 \mathrm{~h}$ for feed. Bags were exchanged under anaerobic conditions using $\mathrm{CO}_{2}$ to flush the fermenters. To maintain conditions as close to those of the in vivo rumen as possible, the incubation temperature was $39^{\circ} \mathrm{C}$ and rumen fluid turnover was simulated by a continuous buffer perfusion at a rate of $750 \mathrm{ml} /$ day. The chemical composition of the buffer solution is presented in Table 2. The $\mathrm{pH}$ was 7.4 and the osmolality was $293 \mathrm{mosmol} / \mathrm{l}$. By moving the inner vessel up and down continuously rumen motility was simulated and exchange between the fluid and particle phases was facilitated. Rumen gas was collected in gastight collecting sacs to ensure a closed system; the fluid outflow was collected in ice-cooled Erlenmeyer flasks to stop microbial activity and preserve fermentation products.

Table 2: Chemical composition of the buffer solution ( $\mathrm{mmol} / \mathrm{l})$. Table 2: Tampon çözeltinin kimyasal bileşimi (mmol/l).

\begin{tabular}{lc}
\hline Ingredient & \\
\hline $\mathrm{NaCl}$ & 28.00 \\
$\mathrm{KCl}$ & 7.69 \\
$\mathrm{CaCl} \cdot 2 \mathrm{H}_{2} \mathrm{O}$ & 0.22 \\
$\mathrm{MgCl}_{2} \cdot 6 \mathrm{H}_{2} \mathrm{O}$ & 0.63 \\
$\mathrm{NH}_{4} \mathrm{Cl}$ & 5.00 \\
$\mathrm{Na}_{2} \mathrm{HPO}_{4} \cdot 12 \mathrm{H}_{2} \mathrm{O}$ & 10.00 \\
$\mathrm{NaH}_{2} \mathrm{PO}_{4} \cdot \mathrm{H}_{2} \mathrm{O}$ & 10.00 \\
$\mathrm{NaHCO}_{3}$ & 97.90 \\
\hline
\end{tabular}

Preparation of propolis extracts: Ethanolic extracts of propolis were prepared as described previously by Sforcin et al. (25). Crude propolis was ground into a fine powder, and thereafter $20 \%$ and $60 \%$ ethanolic extracts of propolis were prepared $(2 \mathrm{~g}$ and $6 \mathrm{~g}$ propolis powders were completed to $10 \mathrm{ml}$ with $70 \%$ ethyl alcohol), protected from light, with moderate shaking, at room temperature. After a week, the insoluble fraction was separated by filtration. The filtrate was named ethanolic extract of propolis and was maintained in caramel flask in dark at room temperature.

Experimental procedure: Six fermenters of the Rusitec were run for a total period of 14 days. The first 7 days were allowed for equilibration of the system. The following 7 days represented an experimental period during which the six fermenters were divided into 3 groups with two fermenters per group. The first group served as control and received daily $0.5 \mathrm{ml}$ of $70 \%$ ethyl alcohol in water (without having any propolis). The second and third groups received daily $0.5 \mathrm{ml}$ of $20 \%$ PEE (contained active substances of $100 \mathrm{mg}$ crude propolis) and $0.5 \mathrm{ml}$ of $60 \%$ PEE (contained active substances of $300 \mathrm{mg}$ crude propolis), respectively.

Analytical procedures and samplings: The $\mathrm{pH}$ values were measured daily in each fermenter at the time of feeding using an epoxy body $\mathrm{pH}$ electrode (WD35801-00, Oakton) connected to a pH-meter (Ion 6, Acorn series, Oakton). $5 \mathrm{ml}$ of liquid effluents, collected in ice-cold flasks, were taken daily, and immediately 
acidified with $0.4 \mathrm{ml}$ of dilute $\mathrm{HCl}(9.25 \%)$ and frozen at $-20^{\circ} \mathrm{C}$ until analysed for ammonia nitrogen. Samples of the effluents were also collected daily and kept at $-20^{\circ} \mathrm{C}$ until SCFA analysis. Ruminal SCFA samples were allowed to thaw completely at $4{ }^{\circ} \mathrm{C}$ before analysis. Samples were then acidified $(\mathrm{pH}<3)$ with $90 \mu \mathrm{l}$ of $12 \mathrm{~N}$ $\mathrm{H}_{2} \mathrm{SO}_{4}$, vortexed, and centrifuged (Universal 32R, Hettich Zentrifugen, Germany) in Eppendorf tubes for 30 $\min$ at $13000 \mathrm{rpm}$. The supernatant was filtered through a $0.2 \mu \mathrm{m}$ PTFE membrane (Millex-GN, Millipore). Concentrations of SCFA in the supernatant were then determined by HPLC (Dionex Summit P680, ASI100) equipped with an UV absorbance detector (Dionex UVD170) operated at $210 \mathrm{~nm}$. Separation of acids was conducted using an organic acid analysis column $(300 \mathrm{x}$ $7.8 \mathrm{~mm}$; Rezex ROA-Organic Acid column), with 0.005 $\mathrm{M} \mathrm{H}_{2} \mathrm{SO}_{4}$ as eluent, at flow rate of $0.6 \mathrm{ml} / \mathrm{min}$, and with the column temperature of $60^{\circ} \mathrm{C}$. A Rezex ROA Organic Acid precolumn $(50 \times 7.8 \mathrm{~mm})$ was used to protect the column from any particles that could have been injected together with the samples. Daily production rates of SCFA were estimated by multiplying the respective concentration by the volume of effluent collected. Ruminal $\mathrm{NH}_{3}-\mathrm{N}$ samples were allowed to thaw completely at $4^{\circ} \mathrm{C}$ before analysis. $\mathrm{NH}_{3}-\mathrm{N}$ concentrations were determined by means of an ammonia gas sensing electrode (Ammonia combination electrode, ColeParmer; calibrated daily with serial dilutions of an $\mathrm{NH}_{4} \mathrm{Cl}$ stock solution) connected to an Acorn series Ion meter (Oakton Instruments, USA). For bacteria and protozoa counting, rumen fluid samples of fermenters were taken daily immediately before substrate exchange. For protozoa counting, $1 \mathrm{ml}$ of sample was carefully mixed with $1 \mathrm{ml}$ of a solution of $0.6 \mathrm{~g}$ methyl green, $6 \mathrm{~g} \mathrm{NaCl}$ and $100 \mathrm{ml}$ formaldehyde (37\%) filled up to $1000 \mathrm{ml}$ aqua dest. Portions of the samples were then pipetted into a counting chamber (Fuchs-Rosenthal: $0.0625 \mathrm{~mm}^{2} ; 0.2$ $\mathrm{mm}$ deep; Marienfeld, Germany). Total numbers of protozoa, without quantifying different types, were determined using a light microscope (Leica CME). For bacteria counting, $0.1 \mathrm{ml}$ rumen fluid was mixed with 0.9 $\mathrm{ml} \mathrm{37 \%} \mathrm{formaldehyde.} \mathrm{Direct} \mathrm{counts} \mathrm{of} \mathrm{total} \mathrm{bacteria}$ were made using a cell chamber (Thoma: $0.0025 \mathrm{~mm}^{2}$ squares, $0.02 \mathrm{~mm}$ deep; Brand, Germany) under phasecontrast microscope (Olympus Optical Co., Japan). Dry matter was determined by drying at $65^{\circ} \mathrm{C}$ for $48 \mathrm{~h}$. The digestibility of dry matter at $48 \mathrm{~h}$ was calculated as original dry matter sample weight minus dry matter residue weight divided by the original sample weight. This value was then multiplied by 100 to derive the digestibility of dry matter percentage.

Statistical analyses: Data are expressed as mean \pm standard deviation (SD) and were evaluated by one-way repeated measures analysis of variance (ANOVA) followed by the Duncan's multiple range test for all pairwise multiple comparisons. The analyses were performed using the Sigmastat 3.1 statistical software (Systat Software, Erkrath, Germany) and the mean differences were considered statistically significant when $\mathrm{p}$ values were less than 0.05 .

\section{Results}

Effects of different concentrations of PEE on in vitro rumen microbial fermentation are shown in Table 3. Increasing concentrations of PEE did not significantly affect $(p>0.05)$ ruminal $\mathrm{pH}$, when compared with the control fermenters. Total SCFA production was not statistically changed $(p>0.05)$ by both PEE concentrations. The addition of both low and high concentrations of PEE did not change $(p>0.05)$ the production of acetate but significantly increased $(p<0.05)$ the production of butyrate. Relative the control, only the addition of $60 \%$ PEE significantly reduced $(\mathrm{p}<0.05)$ the production of propionate. The ratio of acetate to propionate was not significantly affected $(p>0.05)$ by both PEE concentrations compared with the control.

Table 3: Effects of different concentrations of PEE on in vitro rumen microbial fermentation.

Table 3: Farklı yoğunluktaki etanolik propolis ekstraktlarının rumen mikrobiyal fermantasyonuna in vitro etkileri.

\begin{tabular}{|c|c|c|c|}
\hline Items & $\begin{array}{c}\text { control } \\
70 \% \text { ethanol } \\
\text { without } \\
\text { propolis } \\
(0.5 \mathrm{ml} / \text { day })\end{array}$ & $\begin{array}{c}20 \% \text { PEE } \\
(0.5 \mathrm{ml} / \text { day })\end{array}$ & $\begin{array}{c}60 \% \text { PEE } \\
(0.5 \mathrm{ml} / \mathrm{day})\end{array}$ \\
\hline $\mathrm{pH}$ & $6.80 \pm 0.01$ & $6.81 \pm 0.01$ & $6.80 \pm 0.02$ \\
\hline $\begin{array}{l}\text { Total SCFAs } \\
\text { (mmol/day) }\end{array}$ & $37.87 \pm 1.51$ & $38.13 \pm 1.97$ & $37.23 \pm 1.84$ \\
\hline Acetate & $23.83 \pm 0.94$ & $23.78 \pm 1.72$ & $23.51 \pm 1.25$ \\
\hline Propionate & $11.15 \pm 0.79^{\mathrm{a}}$ & $11.18 \pm 0.59^{\mathrm{a}}$ & $10.59 \pm 0.79^{b}$ \\
\hline Butyrate & $2.89 \pm 0.25^{\mathrm{a}}$ & $3.17 \pm 0.29^{b}$ & $3.13 \pm 0.34^{b}$ \\
\hline $\begin{array}{l}\text { Acetate : } \\
\text { propionate ratio }\end{array}$ & $2.14 \pm 0.14$ & $2.13 \pm 0.18$ & $2.23 \pm 0.16$ \\
\hline $\begin{array}{l}\text { Total bacteria } \\
\left(\mathrm{x} 10^{8} / \mathrm{ml}\right)\end{array}$ & $16.35 \pm 0.70^{\mathrm{a}}$ & $15.47 \pm 1.18^{\mathrm{b}}$ & $14.84 \pm 1.30^{\mathrm{b}}$ \\
\hline $\begin{array}{l}\text { Total protozoa } \\
\left(\mathrm{x} 10^{3} / \mathrm{ml}\right)\end{array}$ & $2.81 \pm 0.32$ & $2.90 \pm 0.31$ & $3.04 \pm 0.41$ \\
\hline $\mathrm{NH}_{3}-\mathrm{N}(\mathrm{mmol} / \mathrm{l})$ & $9.51 \pm 0.35^{\mathrm{a}}$ & $7.25 \pm 0.57^{\mathrm{b}}$ & $5.78 \pm 0.28^{\mathrm{c}}$ \\
\hline $\begin{array}{l}\text { Dry matter } \\
\text { digestibility (\%) }\end{array}$ & $62.93 \pm 2.53$ & $62.43 \pm 2.10$ & $61.21 \pm 3.47$ \\
\hline
\end{tabular}

In the present study, addition of both concentrations of PEE significantly reduced $(\mathrm{p}<0.05)$ the numbers of ruminal bacteria. However, propolis at both concentrations did not significantly affect $(p>0.05)$ the 
numbers of ruminal ciliate protozoa and dry matter digestibility of diets incubated for $48 \mathrm{~h}$ in the Rusitec fermenters.

\section{Discussion and Conclusion}

Until recently, only few reports were found in the literature dealing with the effects of propolis on ruminal fermentation. Broudiscou et al. (2) found that addition of $500 \mathrm{mg} / \mathrm{l}$ of propolis extract increased propionate production without affecting other ruminal fatty acids in dual outflow fermenters supplied with a 50:50 orchard grass hay plus barley diet. Stradiotti Jr. et al. (26) reported that propolis extract increased the total SCFA concentration in Holstein steers fed a diet containing $65 \%$ forage and $35 \%$ concentrate. On the other hand, these latter authors (26) underlined that the molar proportions of ruminal SCFA were not changed by propolis treatment. Furthermore, Lana et al. $(12,13)$ showed that supplementation of propolis (up to 6 $\mathrm{g} /$ animal/day) did not affect total and individual SCFA concentrations in dairy goats fed a diet of $67 \%$ corn silage and $33 \%$ concentrate.

There are no data about the effect of propolis on ruminal bacteria. However, the antibacterial effect of propolis on different bacterial strains has been shown by several authors $(10,21,24,25)$. Although little is known about the mechanisms of propolis antibacterial action, Takaisi-Kikuni and Schilder (27) observed that the antibacterial action against Streptococcus agalactiae was complex, involving several mechanisms such as the formation of pseudo-multicellular streptococci; disorganization of the cytoplasm, the cytoplasmatic membrane, and the cell wall; partial bacteriolysis; and inhibition of protein synthesis. In another study conducted by Mirzoeva et al. (15), propolis and some of the cinnamic and flavonoid components were found to uncouple the energy transducing cytoplasmic membrane and to inhibit bacterial motility, which may contribute to the antimicrobial action.

Only two reports deal with the effect of propolis on rumen ciliate protozoa $(2,22)$. In Broudiscou's study (2) propolis $(0.5 \mathrm{~g} / \mathrm{l})$ did not significantly change the counts of rumen ciliates in dual outflow fermenters. However, Rispoli et al. (22) found that propolis extract reduced the numbers of ciliates in the rumen of buffaloes fed a diet consisting of corn silage and concentrate (50:50) but not in cattle fed the same diet. The reason for non-beneficial effect of propolis on ruminal SCFA may be due to the lack of its inhibitory effect on rumen ciliates. Rumen ciliates contribute to the greater part of ruminal methanogenesis via hydrogen supply to the endosymbiotic and episymbiotic methanogens (9). Inhibition of protozoa reduces methane release by diverting reducing equivalents from methane to propionate synthesis in the rumen $(7,11)$. Such a change is nutritionally beneficial to the ruminal energetic metabolism because propionate is the gluconeogenic SCFA and it is more efficiently utilized by ruminant than other SCFA.

The present experiment showed that $\mathrm{NH}_{3}-\mathrm{N}$ concentrations decreased $(p<0.05)$ in a dose-dependent manner when ruminal fluid was incubated with increasing levels of propolis, which is consistent with previous reports $(18,19,26)$. In the Rusitec, ruminal $\mathrm{NH}_{3}-\mathrm{N}$ concentration is determined by the balance between amino acids deamination and $\mathrm{NH}_{3}-\mathrm{N}$ utilization by ruminal microorganisms (20). Decreased $\mathrm{NH}_{3}-\mathrm{N}$ concentration observed in this study, therefore, may be associated with reduced deamination of amino acids and/or reduced growth rate of amino acid-fermenting bacteria in the presence of propolis. This result was confirmed by lower bacterial counts in the Rusitec fermenters supplemented with PEE. PEE at both levels did not affect dry matter digestibility of diets incubated for $48 \mathrm{~h}$ in the Rusitec fermenters. This finding is agreement with previous studies $(3,12)$.

In conclusion, the present study showed that propolis at assayed doses did not improve the production rate and the profile of ruminal SCFA and it would not be nutritionally beneficial to the ruminal energetic metabolism. However, propolis was able to inhibit ruminal $\mathrm{NH}_{3}-\mathrm{N}$ concentration. This ammonia-reducing effect may help to improve the nitrogen retention in ruminants.

\section{Acknowledgment}

The authors are grateful to Associate Professor Murat Kartal (Department of Pharmacognosy, Faculty of Pharmacy, University of Ankara, Turkey) for providing the propolis sample.

\section{References}

1. Banskota AH, Tezuka Y, Kadota S (2001): Recent progress in pharmacological research of propolis. Phytother Res, 15, 561-571.

2. Broudiscou LP, Papon Y, Broudiscou AF (2000): Effects of dry extracts on fermentation and methanogenesis in continuous culture of rumen microbes. Anim Feed Sci Tech, 87, 263-277.

3. Broudiscou LP, Papon Y, Broudiscou A (2002): Effects of dry plant extracts on feed degradation and the production of rumen microbial biomass in a dual outflow fermenter. Anim Feed Sci Tech, 101, 183-189.

4. Burdock GA (1998): Review of the biological properties and toxicity of propolis. Food Chem Toxicol, 36, 341-363.

5. Crane E (1997): The past and present importance of bee products to man. 1-14. In: A Mizrahi, Y Lensky (Ed), Bee Products: Properties, Applications, and Apitherapy. Plenum Press, New York.

6. Czerkawski JW, Breckenridge G (1977): Design and development of a long-term rumen simulation technique (Rusitec). Brit J Nutr, 38, 371-384. 
7. Demeyer D, Van Nevel CJ (1975): Methanogenesis, an integrated part of carbohydrate fermentation and its control. 366-382. In: LW McDonald, ACI Warner (Ed), Digestion and Metabolism in the Ruminant. University of New England Publishing Unit, Armidale, Australia.

8. Gonsales GZ, Orsi RO, Fernandes A, Rodrigues P, Funari SRC (2006): Antibacterial activity of propolis collected in different regions of Brazil. J Venom Anim Toxins, 12, 276-284.

9. Irbis C, Ushida K (2004): Detection of methanogens and proteobacteria from a single cell of rumen ciliate protozoa. J Gen Appl Microbiol, 50, 203-212.

10. Kartal M, Yıldız S, Kaya S, Kurucu S, Topçu G (2003): Antimicrobial activity of propolis samples from different regions of Anatolia. J Ethnopharmacol, 86, 69-73.

11. Kreuzer M, Kirchgessner M, Müller HL (1986): Effect of defaunation on the loss of energy in wethers fed different quantities of cellulose and normal or steamflaked maize starch. Anim Feed Sci Tech, 16, 233-241.

12. Lana RP, Camardelli MML, Queiroz AC, Rodrigues MT, Eifert EC, Miranda EN, Almeida ICC (2005): Soybean oil and propolis in the diets of dairy goats. Rev Bras Zootecn, 34, 650-658.

13. Lana RP, Camardelli MML, Rodrigues MT, Eifert EC, Oliveira MVM, Stradiotti JD, Oliveira JS (2007): Soybean oil and propolis in the diets of dairy goats: intake of nutrients and ruminal metabolism. Rev Bras Zootecn, 36, 191-197.

14. McGuffey RK, Richardson LF, Wilkinson JID (2001): Ionophore for dairy cattle: Current status and future outlook. J Dairy Sci, 84 (E. Suppl.), E194-E203.

15. Mirzoeva OK, Grishanin RN, Calder PC (1997): Antimicrobial action of propolis and some of its components: the effects on growth, membrane potential and motility of bacteria. Microbiol Res, 152, 239-246.

16. Oeztuerk H, Schroeder B, Beyerbach M, Breves G (2005): Influence of living and autoclaved yeasts of Saccharomyces boulardii on in vitro ruminal microbial metabolism. J Dairy Sci, 88, 2594-2600.

17. Oeztuerk H, Sagmanligil V (2009): Role of live yeasts on rumen ecosystem. Deut Tierarztl Woch, 116, 244-248.

18. Oliveira JS, Lana RP, Borges AC, Queiroz AC, Almeida ICC (2004): Effect of monensin and propolis extract on ammonia production and in vitro degradability of crude protein of different nitrogen sources. Rev Bras Zootecn, 33, 504-510.
19. Oliveira JS, Queiroz AC, Lana RP, Montovani HC, Generoso RAR (2006): Effect of monensin and bee propolis on in vitro fermentation of amino acids by mixed ruminal bacteria. Rev Bras Zootecn, 35, 275-281.

20. Öztürk H (2009): Effects of chicory inulin on ruminal fermentation in vitro. Vet J Ankara Univ, 55, 79-82.

21. Popova M, Silici S, Kaftanoglu O, Bankova V (2005): Antibacterial activity of Turkish propolis and its qualitative and quantitative chemical composition. Phytomedicine, 12, 221-228.

22. Rispoli TB, Rodrigues IL, Martins Neto RG, Kazama R, Prado OPP, Zeoula LM, Arcuri PB (2009): Ruminal ciliate protozoa of cattle and buffalo fed on diet supplemented with monensin or extracts from propolis. Pesqui Agropecu Bras, 44, 92-97.

23. Russell JB, Strobel HJ (1989): Mini-review: The effect of ionophores on ruminal fermentation. Appl Environ Microb, 55, 1-6.

24. Santos FA, Bastos EM, Uzeda M, Carvalho MA, Farias LM, Moreira ES, Braga FC (2002): Antibacterial activity of Brazilian propolis and fractions against oral anaerobic bacteria. J Ethnopharmacol, 80, 1-7.

25. Sforcin JM, Fernandes A, Lopes CAM, Bankova V, Funari SRC (2000): Seasonal effect on Brazilian propolis antibacterial activity. J Ethnopharmacol, 73, 243-249.

26. Stradiotti Junior D, Queiroz AC, Lana RP, Pacheco CG, Eifert EC, Nunes PMM (2004): Effect of the propolis on amino acids deamination and ruminal fermentation. Revis Bras Zootecn, 33, 1086-1092.

27. Takaisi-Kikuni NB, Schilder H (1994): Electron microscopic and microcalorimetric investigations of the possible mechanism of the antibacterial action of a defined propolis provenance. Planta Med, 60, 222-227.

Geliş tarihi: 09.09.2009 / Kabul tarihi: 04.01.2010

Address for correspondence:

Dr. Hakan Öztürk

Ankara University, Faculty of Veterinary Medicine

Department of Physiology

06110 Diskapi - Ankara, Turkey

E-mail:hakan.ozturk@veterinary.ankara.edu.tr 